\title{
BEBERAPA PERMASALAHAN PERJANJIAN PEMBIAYAAN KONSUMEN DENGAN JAMINAN FIDUSIA
}

(Some Issues Consumer Financing Agreement with Fiduciary)

\author{
Purwanto \\ BPHN - Kementerian Hukum dan HAM \\ Jl. Mayjen Soetoyo, Cililitan, Jakarta Timur \\ e-mail: purwaspur2001@yahoo.com
}

Naskah diterima: 11 Mei 2012; revisi: 09 Juli 2012; disetujui: 17 Juli 2012

\begin{abstract}
Abstrak
Lembaga pembiayaan konsumen merupakan replika dari pembiayaan perusahaan atau yang dikenal dengan leasing. Lembaga pembiayaan jenis ini berimplikasi pula dengan jenis jaminan. Jaminan merupakan hal penting yang diperlukan dalam setiap perjanjian pinjam meminjam. Dalam bentuk jaminan, dikenal jaminan perorangan dan jaminan kebendaan atau fidusia. Tulisan ini membahas praktek transaksi pembiayaan dengan jaminan fidusia dan pelanggaran yang sering muncul dalam perjanjian pembiayaan konsumen dengan jaminan fidusia. Dari hasil penelitian terlihat bahwa untuk memberikan legitimasi bagi para pihak maka perjanjian dibuat dengan akta otentik, dan didaftarkan pada kantor pendaftaran fidusia guna mendapatkan hak preference bagi kreditur. Eksekusi atas obyek jaminan dalam dalam perjanjian pembiayaan konsumen masih banyak mengalami masalah seperti tidak dilaksanaannya pendaftaran jaminan fidusia pada kantor pendaftaran fidusia sebagaimana diatur dalam undang-undang jaminan fidusia dan peraturan pelaksanaannya. Disamping itu informasi dan pemahaman yang kurang dari debitur atas jaminan fidusia juga mengakibatkan penyelesaian sengketa antara debitur dan kreditur tidak elegan.

Kata kunci: fiducia, jaminan, debitur, kreditur, pembiayaan
\end{abstract}

\section{Abstract}

Consumer finance is a financing alternative that can be given to the consumer of the goods with installment payments are made regularly. General financing agreement with the main guarantee good collateral, guarantees principal and additional collateral to anticipate a default or congestion in loan repayments. The growth of consumer finance agency is actually a replica of the finance company, known as leasing. The types of financial institutions also have implications for the types of collateral. However warranties are important and necessary in any agreement, especially with the lending and borrowing. Regarding the form of guarantees, commonly known personal guarantees and collateral material or fiduciary. In this paper will discuss the transaction and violations that often appear in consumer financing agreement with the fiduciary. From research shows that to provide legitimacy to the parties the agreement made with authentic deed and registered at the registrar's office in order to get the right preference fiduciary for the creditors. The execution of the object of the agreement guarantees the consumer finance is still a lot of problems such as no registration has fiduciary at the registration office as stipulated in fiduciary law and implementing regulations. Besides the lack of information and understanding of the fiduciary debtor also resulted in the settlement of disputes between debtors and creditors are not elegant. Keywords: fiduciary, collateral, debitur, creditur, financing 


\section{A. Pendahuluan}

Pembiayaan konsumen saat ini marak dan berkembang di seluruh wilayah Indonesia, terutama di kota-kota besar. Pembiayaan konsumen yang berkembang dalam sepuluh tahun terakhir ini pada umumnya terfokus pada pembiayaan untuk pembelian kendaraan bermotor, baik untuk roda dua maupun roda empat. Tumbuhnya lembaga pembiayaan konsumen sebenarnya merupakan replika dari pembiayaan perusahaan atau yang dikenal dengan leasing ${ }^{1}$. Ciri khas dari usaha leasing adalah penyewaan atas obyek modal untuk jangka waktu tertentu dimana pada akhir masa sewa terdapat hak opsi atas sewa barang, berupa membeli obyek leasing, menyewa lagi atau tanpa opsi membeli². Senada dengan pembiayaan perusahaan, maka konsumen yang tidak memiliki uang cukup saat ini banyak diberikan talangan oleh lembaga pembiayaan tersebut. Dasarpelaksanaan untukmengimplementasikan pembiayaan konsumen umumnya identik dengan leasing ${ }^{3}$. Untuk melaksanakan perjanjian leasing, faktor terpenting adalah kepercayaan, karenanya itikad baik merupakan kunci dari terlaksananya perjanjian leasing, khususnya dalam hal pembiayaan konsumen.

Berkembangnya lembaga pembiayaan jenis ini berimplikasi pula dengan jenis jaminan. Bagaimanapun jaminan merupakan hal penting dan diperlukan dalam setiap perjanjian, terlebih dengan pinjam meminjam ${ }^{4}$. Mengenai bentuk jaminan, umumnya dikenal jaminan perorangan dan jaminan kebendaan. Dan, salah satu jaminan kebendaan yang dikenal dalam hukum positif adalah jaminan fidusia ${ }^{5}$.

Perjanjian pembiayaan adalah suatu perjanjian penyediaan dana dan atau barang modal yang meliputi antara lain usaha-usaha pembiayaan konsumen, sewa guna usaha (leasing), anjak piutang (factoring), usaha kartu kredit, modal ventura (venture capital) dan perdagangan surat berharga, karenanya perjanjian pembiayaaan ini terkait erat dengan hal keuangan. Pengertian pembiayaan konsumen menurut keputusan Menteri keuangan Nomor 1251/KMK.013/1988, adalah:

"Suatu kegiatan yang dilakukan dalam bentuk penyediaan dana bagi konsumen untuk pembelian barang yang pembayarannya dilakukan secara angsuran". 
Dengan banyaknya usaha-usaha pembiayaan yang ada saat ini, tulisan ini akan membatasi pada perjanjian pembiayaan kredit untuk kendaraan bermotor, yang notabene merupakan bagian dari perjanjian pembiayaan untuk pembiayaan konsumen. Pembiayaan konsumen sesungguhnya adalah kegiatan pembiayaan untuk pengadaan barang berdasarkan kebutuhan konsumen dengan sistem pembayaran angsuran atau kredit, yang bertujuan untuk membantu perorangan ataupun perusahaan dalam pemenuhan kebutuhan dan permodalan mereka, khususnya untuk pembelian kendaraan bermotor. Hal ini ditujukan untuk membantu masyarakat yang memerlukan kendaraaan bermotor tetapi memiliki keterbatasan modal, oleh karena itu dalam perjanjian pembiayaan, pelunasan hutang debitor dilakukan secara angsuran atau kredit ${ }^{6}$. Perjanjian pembiayaan konsumen merupakan suatu bentuk persetujuan dimana pemberi fasilitas / kreditor setuju memberikan pinjaman uang melalui fasilitas pembiayaan dengan Jaminan hak milik secara Fidusia kepada penerima fasilitas pembiayaan/debitor.
Pemberian pinjaman uang dalam perjanjian ini disebut dengan istilah pembiayaan.

Dengan menerima fasilitas dana pembiayaan itu, maka penerima fasilitas menyatakan secara sah berhutang kepada pemberi fasilitas. Dengan tercapainya kesepakatan ini maka pemberi fasilitas berkewajiban untuk mencairkan dana pembiayaan yang merupakan hak bagi penerima fasilitas dan secara otomatis sang debitor memikul kewajiban untuk membayar kembali hutang pembiayaan dengan cara yang telah disepekati. Proses pembiayaan konsumen ini melibatkan tiga pihak (triangular transaction) yaitu perusahaan yang bergerak dibidang pembiayaan konsumen yang melakukan kegiatan usaha berupa penyediaan dana untuk membeli barang yang bertindak sebagai pemberi fasilitas atau kreditor, konsumen sebagai penerima fasilitas atau debitor dan dealer/ supplier/showroom sebagai penyedia barang dan melakukan penjualan. Agar terwujud sikap saling percaya (trustig environment) dan rasa aman (secure) bagi kedua belah pihak, maka pembuatan perjanjian pembiayaan konsumen dilaksanakan dan diikuti dengan penyerahaan Jaminan hak milik secara Fidusia?.

\footnotetext{
6 Ini sesuai dengan tujuan pemerintah yang mengeluarkan kebijakan perkreditan dalam rangka pembangunan, yaitu untuk membantu para pengusaha untuk menambah permodalannya, dalam rangka meningkatkan taraf hidup dari masyarakat golongan ekonomi lemah maupun dari golongan menengah. Hal ini diatur dalam Pasal 1 butir 12 Undang-Undang Nomor 10 Tahun 1992 tentang Pokok-Pokok Perbankan.

7 Sunaryo, Hukum Lembaga Pembiayaan, (Jakarta: Sinar Grafika, 2008), hal 96. Adanya janji bahwa penerima fasilitas memenuhi janji untuk setiap waktu melakukan pencicilan hutang yang dikhawatirkan oleh pihak perusahaan pembiayaan atau pemberi fasilitas tidak akan memenuhi janji itu. Selain itu, mungkin saja jaminan sudah dijual atau dimiliki orang ketiga yang berakibat pemberi fasilitas dirugikan. Penerima fasilitas meskipun tidak memegang hak kepemilikan atas obyek Jaminan Fidusia namun barang Jaminan itu berada dalam tangan penerima fasilitas. Jika hutang pemberi Fidusia/ penerima fasilitas telah dibayar berjumlah sama dengan harga pembelian berikut dengan bunganya maka barang yang dijaminkan menjadi hak miliknya secara utuh. Dengan demikian dapat dihindari kemungkinan bahwa sebelum jumlah total hutang dibayar, barang Jaminannya sudah dijual kepada orang lain. Sebab kalau penerima fasilitas menjualnya, ia dapat dihukum pidana berdasarkan atas pelanggaran Pasal 372 KUHPidana yakni penggelapan barang yang merupakan kejahatan. Dengan perjanjian seperti itu kedua belah pihak tertolong, artinya penerima fasilitas dapat memilik barang dengan mendapatkan dana pembiayaan yang dapat dilunasi secara cicil yang mana ia sendiri tidak mampu membayar secara tunai dan seketika dapat menikmati barangnya, sedangkan dilain pihak pemberi fasilitas merasa aman karena barang Jaminan tidak akan dihilangkan oleh Penerima fasilitas selama hutang belum dibayar lunas karena ia takut terjerat ancaman pidana yakni penggelapan.
} 
Jaminan fidusia sendiri diatur di dalam Undang-Undang Nomor 42 Tahun 1999 tentang Jaminan Fidusia. Di dalam Pasal 1 disebutkan: "Fidusiaadalahpengalihanhakkepemilikansuatu benda atas dasar kepercayaan dengan ketentuan bahwa benda yang hak kepemilikannya dialihkan tetap dalam penguasaan pemilik benda". Jaminan fidusia merupakan hak jaminan atas benda, hak jaminan atas benda bergerak baik yang berwujud maupun yang tidak berwujud dan benda tidak bergerak, khususnya bangunan yang tidak dapat dibebani hak tanggungan sebagaimana dimaksud dalam Undang-undang Nomor 4 Tahun 1996 tentang Hak Tanggungan yang tetap berada dalam penguasaan Pemberi Fidusia, sebagai agunan bagi pelunasan utang tertentu, yang memberikan kedudukan yang diutamakan kepada Penerima Fidusia terhadap kreditor lainnya.

Fidusia merupakan terobosan bagi dunia usaha dan untuk memberikan jaminan kepada investor, oleh karena itu obyek fidusia juga didaftarkan ${ }^{8}$ guna kepentingan investor sendiri. Hal-hal terkait dengan perjanjian lembaga pembiayaan dengan jaminan fidusia ini ini adalah: 1). Piutang, yaitu hak untuk menerima pembayaran; 2). Benda, yaitu segala sesuatu yang dapat dimiliki dan dialihkan, baik yang berwujud maupun yang tidak berwujud, yang terdaftar maupun yang tidak terdaftar, yang bergerak maupun yang tak bergerak yang tidak dapat dibebani hak tanggungan atau hipotek.

\section{B. Permasalahan}

Persoalan yang muncul dalam perjanjian lembaga pembiayaan konsumen umumnya ketika debitur lalai mengembalikan uang pinjaman pada saat yang ditentukan. Hal ini menyebabkan kreditur merasa tidak aman, dan untukmemastikan pengembalianuangnya, maka kreditur tentu akan meminta kepada debitur untuk mengadakan perjanjian tambahan, guna menjamin dilunasinya kewajiban debitur pada waktu yang telah ditentukan, dan disepakati sebelumnya diantara kreditur dan debitur. Oleh karena itu dalam penulisan ini penulis akan membahas 2 (dua) persoalan terkait dengan perjanjian pembiayaan konsumen, yaitu:

1. Bagaimana transaksi pembiayaan konsumen dengan jaminan fidusia ini dilaksanakan?

2. Pelanggaran apa yang sering muncul dalam perjanjian pembiayaan konsumen dengan jaminan fidusia?

\section{Metode Penelitian}

Berdasarkan permasalahan penelitian diatas, penelitian ini dilakukan dengan menggunakan pendekatan yuridis empiris ${ }^{9}$, yaitu pendekatan yang digunakan untuk melihat gejala-gejala sosial yang berkaitan dengan hukum di tengah masyarakat. Pendekatan yuridis empiris mengkaji bagaimana ketentuan normatif diwujudkan senyatanya di masyarakat. 


\section{Pembahasan}

\section{Pembiayaan Konsumen Dengan Jaminan Fidusia}

Fidusia merupakan kata atau istilah dari bahasa asing yang sudah dibakukan ke dalam bahasa Indonesia dan sudah menjadi istilah resmi dalam hukum di Indonesia. Fidusia dalam bahasa Belanda secara lengkap disebut dengan "Fiduciaire Eigendoms Overdracht", dan dalam bahasa Inggris dikenal dengan istilah "Fiduciary Transfer of Ownership"10. Menurut asal katanya, fidusia berasal dari bahasa Latin "fides" yang berarti "kepercayaan"11. Menurut A.Hamzah dan Senjun Manullang Fiducia merupakan suatu cara pengoperan hak milik dari pemiliknya (debitor), berdasarkan adanya suatu perjanjian pokok (perjanjian hutang piutang) kepada kreditor, akan tetapi yang diserahkan hanya haknya saja secara yuridische levering dan hanya dimiliki oleh kreditor secara kepercayaan saja (sebagai jaminan hutang debitor) sedangkan barangnya tetap dikuasai oleh debitor tetapi bukan lagi sebagai eigenaar maupun bezitter melainkan hanya sebagai detentor atau houder untuk dan atas nama kreditor eigenaar". ${ }^{12}$ Sedangkan Munir Fuady menyatakan fidusia ini disebut juga dengan istilah Penyerahan Hak Milik Secara Kepercayaan ${ }^{13}$. Oey Hoey Tiong menyebut bahwa fidusia atau lengkapnya Fiduciaire Eigendoms Overdracht sering disebut sebagai Jaminan Hak Milik Secara Kepercayaan dan merupakan suatu bentuk jaminan atas benda-benda bergerak disamping gadai yang dikembangkan oleh yurisprudensi. ${ }^{14}$ Dan, Gunawan Widjaja \& Ahmad Yani menyatakan bahwa fidusia berdasarkan asal katanya "fides" yang berarti kepercayaan". ${ }^{15}$

Sumber-sumber hukum yang melandasi lembaga jaminan fidusia ini ada yang bersifat umum dan adapula yang bersifat khusus. Aturan yang bersifat umum adalah Pasal 1338 ayat (1) KUHPerdata, yang berbunyi "semua perjanjian yang dibuat secara sah berlaku sebagai undangundang bagi mereka yang membuatnya". Pasal ini memberikan kebebasan kepada para pihak untuk membuat perjanjian yang mereka buat, sepanjang tidak bertentangan dengan undangundang, kesusilaan dan ketertiban umum.

10 Munir Fuady, Jaminan Fidusia, Cet. II, (Bandung: Citra Aditya Bakti, 2003), hlm. 3-4. Dalam literatur Belanda kita jumpai pula pengungkapan jaminan fidusia ini dengan istilah-istilah sebagai berikut: Zekerheids eigendom (hak milik sebagai jaminan); 1. Bezitloos Zekerheidsrecht (jaminan tanpa menguasai); 2. Verruimd Pand Begrip (gadai yang diperluas); 3. Eigendom Overdracht tot Zekerheid (penyerahan hak milik secara jaminan); 4. Bezitloos Pand (gadai tanpa penguasaan); 5. Een Verkapt Pand Recht (gadai berselubung); 6. Uitbaouw dari Pand (gadai yang diperluas).

11 Oey Hoey Tiong, Fiducia Sebagai Jaminan Unsur-Unsur Perikatan, Cet. II, (Jakarta: Ghalia Indonesia, 1985), hlm. 21. Memang konstruksi fidusia adalah, bahwa hubungan hukum antara debitur pemberi fidusia dan kreditur penerima fidusia merupakan suatu hubungan hukum yang berdasarkan atas kepercayaan. Pemberi fidusia percaya bahwa kreditur penerima fidusia mau mengembalikan hak milik yang telah diserahkan kepadanya, setelah debitur melunasi utangnya. Kreditur juga percaya bahwa pemberi fidusia tidak akan menyalahgunakan barang jaminan yang berada dalam kekuasaannya dan mau memelihara barang jaminan tersebut selaku bapak rumah yang baik

12 A. Hamzah dan Senjun Manullang, Lembaga Fidusia Dan Penerapannya Di Indonesia, (Jakarta: Indhill Co., 1987), hlm. 37.

13 Munir Fuady, Op. Cit., hlm. 3.

14 Oey Hoey Tiong, Op. Cit., hlm. 21.

15 Gunawan Widjaja \& Ahmad Yani, Jaminan Fidusia (Seri Hukum Bisnis), Cet. II, (Jakarta: Raja Grafindo Persada, 2001), hlm. 113. 
Sedangkan aturan yang bersifat khusus antara lain: ${ }^{16}$

1) Undang-Undang Nomor 16 Tahun 1985 tentang Rumah Susun, LN.75, TLN.3318;

2) Undang-Undang Nomor 42 Tahun 1999 tentang Jaminan Fidusia, LN.168, TLN.3889;

3) Peraturan Pemerintah Nomor 26 Tahun 1999, LN.58, TLN.3837, jo.Peraturan Pemerintah Nomor 87 Tahun 2000 tentang Tarif Atas Jenis Penerimaan Negara Bukan Pajak Yang Berlaku Pada Departemen Kehakiman, LN.171, TLN.4006;

4) Peraturan Pemerintah Nomor 86 Tahun 2000 tentang Tata Cara Pendaftaran Jaminan Fidusia Dan Biaya Pembuatan Akta Jaminan Fidusia, LN.170, TLN.4005;

5) Keputusan Presiden Nomor 139 Tahun 2000 tanggal 30 September 2000 tentang Pembentukan Kantor Pendaftaran Fidusia Di Setiap Ibukota Propinsi Di Wilayah Negara Republik Indonesia;

6) Keputusan Menteri Kehakiman Dan Hak Asasi Manusia Republik Indonesia Nomor M.01.UM.01.06 Tahun 2000 tanggal 30 Oktober 2000 tentang Bentuk Formulir Dan Tata Cara Pendaftaran Jaminan Fidusia;

7) Keputusan Menteri Kehakiman Dan Hak Asasi Manusia Republik Indonesia Nomor M.08.UM.07.01 Tahun 2000 tanggal 30 Oktober 2000 tentang Pembukaan Kantor Pendaftaran Fidusia;

8) Keputusan Menteri Kehakiman Dan Hak Asasi Manusia Republik Indonesia Nomor M.03-PR.07.10 Tahun 2001 tanggal 30
Maret 2001 tentang Pembukaan Kantor Pendaftaran Fidusia Di Seluruh Kantor Wilayah Departemen Kehakiman Dan Hak Asasi Manusia Republik Indonesia;

9) Surat Edaran Direktur Jenderal Administrasi Hukum Umum Departemen Kehakiman Dan Hak Asasi Manusia Republik Indonesia Nomor C.UM.01.10-11 tanggal 19 Januari 2001 tentang Penghitungan Penetapan Jangka Waktu Penyesuaian Dan Pendaftaran Perjanjian Jaminan Fidusia.

Obyek jaminan fidusia pada awalnya ditujukan hanya untuk benda bergerak, akan tetapi dalam perkembangannya, obyek fidusia tidak hanya benda bergerak saja, tetapi juga meliputi benda tidak bergerak ${ }^{17}$. Hal ini dapat dilihat dari ketentuan sebagaimana dituangkan dalam Undang-Undang Nomor 42 Tahun 1999 tentang Jaminan Fidusia, yang menyebutkan bahwa obyek jaminan fidusia adalah benda bergerak baik yang berwujud maupun yang tidak berwujud, yang terdaftar maupun yang tidak terdaftar dan benda tidak bergerak yang tidak dapat dibebani hak tanggungan maupun hipotik $^{18}$. Sedangkan J. Satrio menyatakan bahwa benda yang dapat menjadi obyek Jaminan Fidusia sekarang ini meliputi: Benda Bergerak dan Benda Tetap Tertentu yaitu benda tetap yang tidak bisa dijaminkan melalui lembaga jaminan hak tanggungan atau hipotik dan dengan syarat benda tetap tersebut dapat dimiliki dan dapat dialihkan. ${ }^{19}$

Lebih lanjut dalam ketetuan Pasal 3 UndangUndang Nomor 42 Tahun 1999 tentang Jaminan

A.Hamzah dan Senjun Manullang, Op.Cit., hlm. 41-42.

17 Hal ini dapat dilihat dari Keputusan Pengadilan Tinggi Surabaya Nomor 158/1950/Pdt tanggal 22 Maret 1950 dan Keputusan Mahkamah Agung Nomor 372 K/Sip/1970 tanggal 1 September 1971, yang menyatakan bahwa fidusia hanya sah sepanjang mengenai barang-barang bergerak.

18 Lihat Undang-Undang Nomor 42 Tahun 1999 tentang Jaminan Fidusia,Pasal 1 ayat (2) dan ayat (4).

19 J. Satrio, Hukum Jaminan, Hak Jaminan Kebendaan Fidusia, (Bandung: Citra Aditya Bakti, 2002), hlm. 179. 
Fidusia menyatakan, bahwa Jaminan Fidusia tidak berlaku terhadap:

1. Hak tanggungan yang berkaitan dengan tanah dan bangunan, sepanjang peraturan perundang-undangan yang berlaku menentukan jaminan atas benda-benda tersebut wajib didaftar;

2. Hipotek atas kapal yang terdaftar dengan isi kotor berukuran 20 (dua puluh) M3 atau lebih;

3. Hipotek atas pesawat terbang; dan

4. Gadai.

Dengan demikian, obyek jaminan fidusia adalah benda bergerak dan benda tidak bergerak, khususnya bangunan yang tidak bisa dibebani dengan hak tanggungan. Akan tetapi dalam prakteknya, kebanyakan jaminan fidusia berupa benda bergerak, antara lain kendaraan bermotor, stok barang dagangan (inventory). Sedangkan jaminan fidusia berupa benda tidak bergerak seperti kios jarang digunakan. Hal ini berkaitan dengan tempat pendaftaran yang dirasakan kurang menjamin kepastian hukum terhadap kreditur, dan kemungkinan menghadapi kesulitan lebih besar dibandingkan dengan benda bergerak dalam eksekusi benda jaminan dikemudian hari. Sehingga secara praktis obyek jaminan fidusia hanya berupa benda bergerak saja.

Mengenai benda yang menjadi jaminan fidusia, Undang-Undang Fidusia pada Pasal 5 ayat (1) menentukan, bahwa pembebanan benda dengan jaminan fidusia dibuat dengan akta notaris dalam bahasa Indonesia dan merupakan akta jaminan fidusia. Dalam akta jaminan fidusia, selain dicantumkan hari dan tanggal, juga dicantumkan waktu (jam) pembuatan akta tersebut. Dari ketentuan Pasal 5 ayat (1) tersebut, maka pembebanan jaminan fidusia yang merupakan perjanjian fidusia dibuat dalam bentuk tertulis dengan akta notaris ${ }^{20}$.

Di tinjau dari sudut pembuktian yang berlaku di Indonesia, maka akta otentik merupakan alat bukti yang paling kuat dalam hal terjadi sengketa diantara para pihak. Akta otentik merupakan suatu bukti yang sempurna yang tidak bisa dibantah kebenarannya oleh para pihak, kecuali ada unsur penipuan, paksaaan atau kekeliruan yang harus dibuktikan oleh pihak yang membantahnya. Pasal 1870 KUHPerdata menentukan, bahwa: "Suatu akta otentik memberikan diantara para pihak

20 Notaris merupakan pegawai/pejabat umum yang berwenang membuat akta otentik, demikian menurut ketentuan Pasal 1 Peraturan Jabatan Notaris (PJN) yang menyatakan: "Notaris adalah pegawai umum yang satusatunya berwenang untuk membuat akta otentik mengenai semua perbuatan, perjanjian dan ketetapan yang diharuskan oleh sesuatu peraturan umum atau dikehendaki oleh yang berkepentingan agar dinyatakan dalam suatu akta otentik, menjamin kebenaran tanggalnya, menyimpan aktanya dan memberikan grosse, salinan dan kutipannya, semuanya itu sebegitu jauh pembuatan akta-akta itu tidak juga ditugaskan atau dikecualikan kepada pegawai umum lainnya".

Pengertian Notaris menurut Pasal 1 butir (1) Undang-Undang Nomor 30 Tahun 2004 tentang Jabatan Notaris, bahwa Notaris adalah pejabat umum yang berwenang untuk membuat akta otentik dan kewenangan lainnya yang ditentukan dalam Undang-Undang ini.

Pengertian akta otentik sebagaimana yang dinyatakan dalam Pasal 1868 KUHPerdata, bahwa: "Suatu akta otentik ialah suatu akta yang dibuat dalam bentuk yang ditentukan oleh undang-undang, dibuat oleh atau di hadapan pegawai-pegawai umum yang berkuasa untuk itu di tempat di mana akta dibuatnya." Dari pengertian Pasal 1868 KUHPerdata tersebut, maka suatu akta untuk dapat dikatakan akta otentik harus memenuhi 3 (tiga) syarat, yaitu: a. Dibuat oleh atau di hadapan pegawai umum; b. Dibuat dalam bentuk yang ditentukan oleh undangundang; c. Pegawai umum itu berwenang membuat akta itu. 
beserta ahli waris-ahli warisnya atau orangorang yang mendapat hak dari mereka, suatu bukti yang sempurna tentang apa yang dimuat di dalamnya."

Jadi ketentuan untuk pembebanan jaminan fidusia dalam bentuk akta notaris merupakan upaya dalam memberikan kepastian dan perlindungan hukum bagi para pihak yang terkait, karena pada umumnya benda yang menjadi obyek jaminan fidusia adalah barang yang tidak terdaftar.

Dalam fidusia, pendaftaran merupakan syarat mutlak yang harus dipenuhi sebagai syarat lahirnya jaminan fidusia untuk memenuhi asas publisitas. Ini sesuai dengan ketentuan yang terdapat dalam Pasal 11 ayat (1) Undang-Undang Fidusia yang berbunyi: "benda yang dibebani dengan jaminan fidusia wajib didaftarkan".

Pendaftaran tersebut memiliki arti yuridis sebagai suatu rangkaian yang tidak terpisah dari proses terjadinya perjanjian jaminan fidusia, dan selain itu pendaftaran jaminan fidusia merupakan perwujudan dari asas publisitas dan kepastian hukum. ${ }^{21} \mathrm{Hal}$ ini sesuai juga dengan ketentuan dalam Pasal 14 ayat
(3) Undang-Undang Fidusia, bahwa jaminan fidusia lahir pada tanggal yang sama dengan tanggal dicatatnya Jaminan Fidusia dalam Buku Daftar Fidusia. Dalam sistem hukum yang ada pendaftaran meliputi pendaftaran benda dan pendaftaran ikatan jaminan 22 .

Pendaftaran fidusia yang diatur dalam Undang-Undang Fidusia dimaksudkan untuk memberikan kepastian hukum terhadap para pihak yang terkait dalam fidusia. Karena sebelum keluarnya Undang-Undang Fidusia pendaftaran fidusia tidak diwajibkan. Permohonan Pendaftaran Jaminan Fidusia dilakukan oleh pihak penerima fidusia atau wakilnya atau kuasanya dengan melampirkan pernyataan Pendaftaran Jaminan Fidusia, hal ini sesuai dengan Pasal 13 ayat (1) UndangUndang Nomor 42 Tahun 1999 tentang Jaminan Fidusia. Permohonan pendaftaran jaminan fidusia tersebut dibuat secara tertulis dalam bahasa Indonesia dan ditujukan kepada Menteri Kehakiman dan Hak Asasi Manusia melalui Kantor Pendaftaran Fidusia, sebagaimana diatur dalam Pasal 2 Peraturan Pemerintah Nomor 86 Tahun 2000 tentang Tata Cara Pendaftaran

21 Tan Kamelo, Hukum Jaminan Fidusia Suatu Kebutuhan Yang Didambakan, Edisi Pertama, Cetakan Kedua, (Bandung: Alumni, 2006), hlm. 213.

22 Pendaftaran suatu benda merupakan suatu pembukuan/registrasi benda tertentu, dimana dalam buku register tersebut dicatat dengan teliti ciri-ciri benda dan pemilik benda yang bersangkutan, dan benda yang telah didaftarkan tersebut disebut dengan istilah benda terdaftar atau benda atas nama. Berdasarkan keterangan di atas, maka orang yang namanya terdaftar dalam buku pendaftaran benda/register menjadi pemilik dari benda yang bersangkutan. Dengan demikian hak dari pemilik benda menjadi terdaftar yang kemudian terhadap pemilik benda terdaftar tersebut akan dikeluarkan bukti kepemilikan. Selain itu karena hak yang terdaftar adalah hak si pemilik atas suatu benda, maka berdasarkan Pasal 584 Kitab Undang-Undang Hukum Perdata, hak si pemilik merupakan hak kebendaan, suatu hak yang bersifat absolute, sehingga bisa ditujukan dan dipertahankan terhadap siapa saja. Hal lain yang juga berkaitan dengan sifat kebendaan adalah droit de suite. Terhadap benda yang telah didaftarkan atau benda terdaftar dalam penyerahan dan pembebanannya dilakukan dengan mendaftarkan kata peralihannya atau akta pembebanannya dalam buku register yang bersangkutan. Terhadap benda terdaftar ini, bagi pihak ketiga yang melakukan pengoperan atau melakukan pemindahan hak dari pihak yang tidak berhak, tidak dapat membenarkan perolehannya hanya berdasarkan itikad baik semata. Sedangkan pendaftaran ikatan jaminan yang berlaku dalam sistem hokum kita adalah Pendaftaran ikatan jaminan atas benda terdaftar. Contohnya adalah ikatan jaminan yang ada pada hipotik dan hak tanggungan, dimana ikatan jaminannya merupakan ikatan jaminan terhadap benda terdaftar. Keadaan yang sama juga berlaku terhadap tanah dimana tanah yang akan dijadikan jaminan harus didaftarkan dahulu baru bisa dijadikan jaminan. 
Jaminan Fidusia dan Biaya Pembuatan Akta Jaminan Fidusia.

Permohonan pendaftaran fidusia dilakukan oleh penerima fidusia atau wakilnya atau kuasanya dengan melampirkan pernyataan pendaftaran jaminan fidusia, yang memuat: 1 ) Identitas pihak pemberi dan penerima fidusia; 2)Tanggal, nomor akta jaminan fidusia, nama, dan tempat kedudukan notaris yang membuat akta jaminan fidusia; 3) Data perjanjian pokok yang dijamin fidusia; 4) Uraian mengenai benda yang menjadi obyek jaminan fidusia; 5) Nilai penjaminan; 6) Nilai benda yang menjadi obyek jaminan fidusia. Sebagai bukti bahwa kreditur telah melakukan pendaftaran jaminan fidusia adalah diterbitkannya sertifikat jaminan fidusia oleh Kantor Pendaftaran Fidusia, pada hari pendaftaran dilakukan. Sertifikat jaminan fidusia mempunyai kekuatan eksekutorial yang dipersamakan dengan Putusan Pengadilan yang telah mempunyai kekuatan hokum tetap. Artinya bahwa sertifikat jaminan fidusia dapat langsung dipakai sebagai alat eksekusi terhadap obyek jaminan fidusia tanpa melalui proses pengadilan, bersifat final dan mengikat. Apabila setelah didaftarkan terjadi perubahan dalam hal jaminan fidusia, maka penerima fidusia wajib mengajukan permohonan pendaftaran atas perubahan tersebut ke Kantor Pendaftaran Fidusia, dan perubahan tersebut tidak perlu dilakukan dengan akta notaris.

Pendaftaran jaminan fidusia dilakukan di Kantor Pendaftaran Fidusia, sesuai dengan ketentuan yang terdapat dalam Pasal 12 UndangUndang Fidusia. Kantor Pendaftaran Fidusia berada dalam lingkup Departemen Hukum dan Hak Asasi Manusia Republik Indonesia yang bertempat di Jakarta. Kantor pendaftaran
Fidusia didirikan untuk pertama kali di Jakarta dan secara bertahap sesuai keperluan akan didirikan di ibukota propinsi di seluruh Wilayah Negara Republik Indonesia. Hal ini sesuai dengan Keputusan Presiden Nomor 139 Tahun 2000 tentang Pembentukan Kantor Pendaftaran Fidusia di Setiap Ibukota Propinsi di Wilayah Negara Republik Indonesia, bahwa Kantor Pendaftaran Fidusia didirikan di setiap ibukota propinsi dan berada dalam lingkup Kantor Wilayah Departemen Hukum dan Hak Asasi Manusia Republik Indonesia. Sedangkan untuk pendirian Kantor Pendaftaran Fidusia di daerah tingkat II dapat disesuaikan dengan Undangundang tentang Pemerintahan Daerah, hal ini sesuai dengan keterangan dalam penjelasan Pasal 12 Undang-Undang Fidusia.

Dengan dilakukannya pendaftaran jaminan fidusia di Kantor Pandaftaran Fidusia serta diterbitkannya sertifikat jaminan fidusia, maka benda atau obyek yang menjadi jaminan fidusia juga beralih kepemilikannya dari pemberi kepada penerima fidusia, walaupun penguasaannya diberikan secara sukarela kepada pemberi fidusia. Pemberi fidusia tidak lagi berhak untuk memperjualbelikan atau memindahtangankan obyek jaminan fidusia tersebut, kecuali untuk obyek jaminan fidusia yang berupa benda persediaan/stok barang dagangan (inventory). Pemberi fidusia bertanggungjawab penuh terhadap keselamatan obyek jaminan fidusia sebagai akibat pemakaian dan keadaan obyek jaminan fidusia yang berada dalam penguasaannya karena obyek jaminan fidusia sepenuhnya berada dalam penguasaan pemberi fidusia termasuk memperoleh manfaat dari obyek jaminan fidusia tersebut. ${ }^{23}$ Bagi penerima fidusia setelah dilakukan pendaftaran jaminan

23 Gunawan Widjaja \& Ahmad Yani, Op. Cit., hlm. 129. 
fidusia, maka penerima fidusia menjadi kreditur preferen atau mempunyai hak didahulukan untuk mengambil pelunasan piutangnya atas hasil eksekusi benda yang menjadi obyek jaminan fidusia. Dengan diterbitkannya sertifikat jaminan fidusia, maka penerima fidusia mempunyai hak eksekutorial yaitu penerima fidusia langsung dapat melaksanakan eksekusi terhadap obyek jaminan fidusia apabila pemberi fidusia melakukan cidera janji terhadap pelunasan utang yang dijamin dengan benda yang menjadi obyek jaminan fidusia tanpa harus melalui pangadilan dan bersifat final serta mengikat para pihak untuk melaksanakannya.

Jaminan fidusia akan hapus manakala hutang yang dijamin dengan fidusia hapus, adanya pelepasan hak atas jaminan fidusia oleh penerima fidusia, dan benda yang menjadi obyek jaminan fidusia musnah ${ }^{24}$. Dengan hapusnya jaminan fidusia, Kantor Pendaftaran Fidusia akan menerbitkan surat keterangan yang menyatakan sertifikat jaminan fidusia yang bersangkutan tidak berlaku lagi.

\section{Permasalahan Hukum Berkaitan De- ngan Pembiayaan Konsumen Dengan Jaminan Fidusia}

\section{a. Transaksi Pembiayaan Konsumen De- ngan Jaminan Fidusia}

Dalam praktek lembaga pembiayaan konsumen ini sangat diminati oleh para konsumen. Hal ini didasarkan pada alasan-alasan bahwa proses/ prosedur permohonan untuk mendapatkan pembiayaan sangat mudah serta tidak diperlukan adanya jaminan barang-barang lain selain barang yang bersangkutan dijadikan obyek jaminanyang pengikatannya dilakukan secara Fidusia.

Sama seperti pemberian kredit oleh bank, pada lembaga pembiayaan konsumen juga memerlukan jaminan dalam arti keyakinan bagi perusahaan pembiayaan bahwa konsumen akan dapat memenuhi kewajibannya sesuai dengan perjanjian pembiayaan yang telah ditandatangani. Seperti diketahui pemberian pembiayaan oleh perusahaan.

Pembiayaan kepada konsumen dituangkan dalam suatu perjanjian yang namanya perjanjian pembiayaan.

Jaminan-jaminan yang diberikan dalam transaksi pembiayaan konsumen ini pada prinsipnya serupa dengan jaminan terhadap perjanjian kredit bank. Untuk itu, jaminan dalam pembiayaan konsumen dibagi kedalam jaminan utama, jaminan pokok dan jaminan tambahan.

\section{Jaminan utama}

Sebagai suatu kredit, maka jaminan pokoknya adalah kepercayaan dari kreditur (perusahaan pembiayaan) kepada debitur (konsumen), bahwa pihak konsumen dapat dipercaya dan sanggup memenuhi kewajibannya. Jadi disini prinsip pemberian kredit yang dikenal dengan prinsip $5 \mathrm{C}$ (character, capital, capacity, condition ofeconomic dan collateral) juga berlaku dan diterapkan pada pembiayaan konsumen. Untuk mengetahui dan menentukan bahwa seseorang dipercaya untuk memperoleh kredit, pada umumnya dunia perbankan menggunakan instrument analisa $5 \mathrm{C}$ (the five of credit) $\mathrm{ini}^{25}$.

24 Dalam hal benda yang menjadi obyek jaminan fidusia musnah, dan apabila terdapat jaminan asuransinya maka klaim asuransi tersebut menjadi hak dari penerima fidusia. Penerima fidusia mempunyai kewajiban untuk memberitahukan kepada Kantor Pendaftaran Fidusia mengenai hapusnya jaminan fidusia, dengan melampirkan pernyataan mengenai hapusnya hutang, pelepasan hak atau musnahnya benda yang menjadi obyek jaminan fidusia.

25 Sutarno, Aspek-Aspek Hukum Perkreditan Pada Bank, (Bandung: Alfabeta, 2004), hlm. 92. 


\section{Jaminan Pokok}

Sebagai jaminan pokok terhadap transaksi pembiayaan konsumen adalah barang yang dibeli dengan dana atau pembiayaan dari perusahaan pembiayaantersebut. Jika dana tersebut diberikan misalnya untuk membeli mobil, maka mobil yang bersangkutan menjadi jaminan pokoknya. Biasanya jaminan tersebut dibuat dalam bentuk "Fiduciary Transfer of Ownership" (Fidusia). ${ }^{26}$

Mengingat dalam pembiayaan konsumen umumnya adalah barang kebutuhan konsumen, seperti; komputer, alat elektronik, alat berat, kendaraan bermotor, dan lain-lainnya, yang notabena masuk katagori barang bergerak, maka pembebanannya atau pengikatannya memakai lembaga jaminan fidusia.

\section{Jaminan Tambahan}

Sering juga dalam praktek pembiayaan konsumen dimintakan jaminan tambahan, walaupun tidakseketatjaminan untuk pemberian kredit oleh bank. Dalam pengamatan Munir Fuady, biasanya jaminan tambahan terhadap transaksi ini adalah berupa: Surat pengakuan utang (promissory notes), atau acknowledgment of indebtedues, kuasa menjual barang, dan assignment of proceed (cossie) dari asuransi. Disamping itu sering juga dimintakan "persetujuan istri/suami" untuk konsumen pribadi, dan persetujuan komisaris / RUPS untuk konsumen perusahaan sesuai ketentuan Anggaran Dasarnya ${ }^{27}$.

Pembebanan atau pengikatan barang yang menjadi obyek pembiayaan konsumen dilakukan dengan membuatkan perjanjian tambahan yaitu perjanjian pemberian jaminan fidusia yang mengikuti perjanjian pokoknya yaitu perjanjian pembiayaan konsumen.

Pada dasarnya dalam pelaksanaan perjanjian pembiayaan konsumen di Indonesia, tidak hanya dibuat satu macam perjanjian yang dibuat oleh para pihak, tetapi juga dibuat berbagai jenis perjanjian lainnya. Perjanjian pokoknya adalah perjanjian pembiayaan konsumen, dan dari perjanjian pembiayaan ini, maka lahirlah perjanjian tambahan atau perjanjian accessoir lainnya, seperti perjanjian jaminan fidusia ${ }^{28}$. Bila dicermati dalam praktek, masing-masing lembaga pembiayaan mempunyai jenis perjanjian tambahan yang berlaku antara satu dengan yang lainnya. Namun yang pasti, pada setiap perjanjian tambahan umumnya ada dibuat perjanjian pemberian jaminan Fidusianya, seperti praktek yang dilakukan selama ini oleh perusahaan pembiayaan.

Perjanjian tambahan tersebut meliputi:

a) Perjanjian pemberian jaminan fidusia

b) Perjanjian oleh debitur

c) Perjanjian pemberian kuasa.

Perjanjian pemberian fidusia merupakan perjanjian yang dibuat antara pemberi fidusia dengan penerima fidusia, dimana pemberi fidusia menyerahkan benda jaminan berdasarkan kepercayaan kepada penerima fidusia, untuk jaminan suatu utang. Pemberi fidusia adalah penerima fasiltiaskredit dari lembaga pembiayaan sedangkan penerima fidusia adalah perusahaan pembiayaan. Biasanya yang diserahkan oleh pemberi fidusia berupa BPKB kendaraan bermotor (barang) yang menjadi obyek perjanjian pembiayaan konsumen. BPKB inilah yang ditahan

\footnotetext{
26 Munir Fuady, Jaminan Fidusia, (Bandung: PT. Citra Aditya, 2000), hlm. 168.

27 Ibid.

28 H. Salim HS, Perkembangan Hukum Kontrak Diluar KUP Perdata, (Jakarta: PT. Raja Grafindo Persada, 2008), hlm. 135.
} 
oleh penerima Fidusia sampai dengan pemberi fidusia dapat melunsi utang-utangnya ${ }^{29}$.

Perjanjian pemberian jaminan fidusia dibuat dengan akta notaries dalam bahasa Indonesia yang merupakan akta jaminan fidusia (pasal 5 ayat 1 UU Jaminan Fidusia. Sejalan dengan ketentuan mengenai hipotik dan hak tanggungan, maka akta jaminan fidusia wajib dibuat dengan akta otentik (akta notaris). Sebagai pejabat yang berwenang untuk membuat akta itu adalah notaris yang ditunjuk undang-undang.

Akta otentik adalah suatu akta yang didalam bentuk ditentukan oleh undang-undang, dibuat oleh atau dihadapan pegawai-pegawai umum yang berkuasa untuk ditempati dimana akta dibuatnya (pasal 1868 KUH Perdata). Sementara R. Supomo memberikan pengertian akta otentik sebagai berikut:

Akta otentik adalah surat yang dibuat oleh atau dimuka seorang pejabat umum yang mempunyai wewenang untuk membuat surat itu, dengan maksud untuk menjadikan surat tersebut sebagai alat bukti ${ }^{30}$. Sedangkan akta dibawah tangan adalah surat yang ditandatangani dan dimuat dengan maksud untuk dijadikan bukti dari perbuatan hukum ${ }^{31}$.

Ketentuan pasal 1870 KUH Perdata menyatakan bahwa akta notaris merupakan akta otentik yang memiliki kekuatan pembuktian sempurna tentang apa yang dimuat didalamnya diantara para pihak beserta para ahli wrisnya, atau para pengganti haknya. Hal inilah yang menyebabkan UU Jaminan fidusia menetapkan perjanjian fidusia harus dibuat dengan akta notaris. ${ }^{32}$

Alasan lain kenapa akta jaminan fidusia harus dibuat dengan akta otentik (akta notaris) adalah mengingat obyek jaminan fidusia tidak saja barang-barang bergerak yang sudah terdaftar, tetapi pada umumnya adalah barang bergerak yang tidak terdaftar, maka sudah sewajarnya bentuk akta otentiklah yang dianggap paling dapat menjamin kepastian hukum berkenaan dengan obyek jaminan fidusia.

Untuk memberikan kepastian hukum, maka pasal 11 UU jaminan fidusia (UU No. 42 tahun 1999) mewajibkan benda yang dibebani jaminan fidusia didaftarkan pada Kantor Pendaftaran Fidusia. Kewajiban ini bahkan tetap berlaku meskipun benda yang dibebani jaminan fidusia berada diluar wilayah Negara Republik Indonesia.

\section{b. Pelanggaran Hukum Perjanjian Lem- baga Pembiayaan Dengan Jaminan Fidusia}

Sulitnya pelaksanaan eksekusi dalam perjanjian pembiayaan konsumen oleh lembaga pembiayaan yang juga merupakan kreditur sesungguhnya merupakan implikasi atas tidak tertibnya pelaksanaan perjanjian. Kewajibankewajiban yang harus ditunaikan oleh pihak kreditur tidak dilaksanaan, sehingga pada kemudian hari terjadi beberapa kesulitan dalam pelaksanaan eksekusi. Di samping itu kurangnya informasi atas jaminan fidusia kepada dibitur juga mengakibatkan pelaksanaan penyelesaian sengketa antara debitur dan kreditur sering terjadi dalam pelaksanaan eksekusi obyek jaminan. Kesulitan-kesulitan ini sebenarnya berkembang atas adanya pelanggaran hukum yang terjadi dalam perjanjian lembaga pembiayaan dengan jaminan fidusia.

Ibid, hlm. 136.

R. Supomo, Hukum Acara Perdata Pengadilan Negeri, (Jakarta: Pradnya Paramita, 1980), hlm. 76-77.

Ibid.

32 Gunawan Widjaja \& Ahmad Yani, Jaminan Fidusia, (Jakarta: PT. Raja Grafindo Persada, 2000), hlm. 136. 
Dapat dimengerti bahwa dalam suatu perjanjian tidak mustahil terjadinya suatu pelanggaran. Demikian halnya dengan perjanjian pembiayaan konsumen dengan jaminan fidusia. Undang-Undang Nomor 42 Tahun 1999 tentang Jaminan Fidusia sebenarnya telah secara tegas dan rinci mengatur tentang tata cara pelaksanaan pendaftaran jaminan fidusia, namun dalam praktek, terjadi berbagai bentuk pelanggaran hukum. Pelanggaran-pelanggaran hukum dilakukan baik oleh pihak kreditur (penerima fidusia) maupun oleh pihak debitur (pemberi fidusia).

\section{Pelanggaran oleh pihak kreditur}

Pelanggaran-pelanggaran yang sering dilakukan oleh kreditur umumnya adalah kreditur tidak mendaftarkan obyek jaminan fidusia di Kantor Pendaftaran Fidusia. Banyak kreditur dari lembaga pembiayaan konsumen tidak mendaftarkan obyek jaminan fidusia di Kantor Pendaftaran Fidusia. Padahal Undang-Undang Nomor 42 Tahun 1999 tentang Fidusia di dalam Pasal 11 ayat (1) secara tegas mengatur bahwa benda yang dibebani dengan jaminan fidusia wajib didaftarkan. Terhadap jaminan fidusia yang tidak didaftarkan maka ketentuan-ketentuan dalam Undang-Undang tentang Jaminan Fidusia tidak berlaku. Dengan kata lain keberlakuan ketentuan-ketentuan yang ada dalam UndangUndang Jaminan Fidusia harus dipenuhi syarat benda jaminan fidusia itu didaftarkan. Oleh karena itu kredituryang tidakmendaftarkan obyek jaminan fidusia di Kantor Pendaftaran Fidusia tidak bisa menikmati keuntungan-keuntungan dari ketentuan-ketentuan dalam undang-undang jaminan fidusia, seperti misalnya hak preferen atau hak didahulukan.

Konsekwensi lain dengan tidak didaftarkannya suatu obyek jaminan fidusia adalah apabila debitur wanprestasi maka kreditur tidak bisa langsung melakukan eksekusi terhadap jaminan fidusia namun harus menempuh gugatan secara perdatadipengadilanberdasarkanketentuanKitab Undang-Undang Hukum Perdata (KUHPerdata). Apabila sudah ada putusan pengadilan yang telah memperoleh kekuatan hukum tetap maka baru dapat dimintakan eksekusi terhadap obyek jaminan fidusia.

Bentuk pelanggaran hukum lainnya yang cukup fatal adalah adanya pendaftaran fidusia yang dilakukan manakala debitur wanprestasi. Hal ini juga masih banyak dilakukan oleh lembaga pembiayaan (finance) dengan alasan sebagaimana telah dikemukakan di atas. Pada saat debitur mulai wanprestasi, perusahaan finance baru mendaftarkan obyek jaminan fidusia dalam rangka untuk memenuhi persyaratan untuk melakukan eksekusi terhadap obyek jaminan fidusia. Pemicu tindakan lembaga finance ini dikarenakan dalam Undang-Undang tentang Jaminan Fidusia tidak diatur ketentuan mengenai daluarsa pendaftaran jaminan fidusia sehingga Kantor Pendaftaran Fidusia tidak punya alasan untuk menolak permohonan pendaftaran fidusia yang perjanjian kreditnya sudah ditandatangani dalam waktu yang lama (biasanya 2-3 tahun sebelum didaftarkan). Meskipun aturan mengenai daluarsa pendaftaran jaminan fidusia tidak ada namun dalam Pasal 14 sub 3 Undang-Undang Nomor 42 Tahun 1999 tentang Jaminan Fidusia telah diatur bahwa jaminan fidusia lahir pada tanggal yang sama dengan tanggal pendaftaran jaminan fidusia sebagaimana tercatat dalam Buku Daftar Fidusia. Oleh sebab itu, apabila ada perjanjian kredit yang dibuat beberapa tahun yang lalu namun pendaftaran jaminan fidusianya baru dilakukan belakangan maka berlakunya jaminan fidusia itu adalah pada saat didaftarkan bukan pada saat perjanjian kredit ditandatangani atau pada saat penandatanganan akta notariil. 
Konsekwensinya adalah peristiwa-peristiwa hukum yang terjadi sebelum pendaftaran jaminan fidusia tidak berlaku ketentuan-ketentuan dalam Undang-Undang tentang Jaminan Fidusia.

Masih terdapat bentuk pelanggaran lain yang cukup signifikan, misalnya kreditur melakukan eksekusi terhadap obyek jaminan fidusia tidak sesuai ketentuan Pasal 29 Undang-Undang tentang Jaminan Fidusia ${ }^{33}$. Apabila debitur wanprestasi dengan tidak melunasi hutangnya sesuai yang diperjanjikan, maka dapat dilakukan eksekusi terhadap obyek jaminan fidusia yang telah didaftarkan di Kantor Pendaftaran Fidusia guna pelunasan utang tersebut.

Hal yang sering dilanggar oleh lembaga pembiayaan (finance) dalam melakukan eksekusi terhadap obyek jaminan umumnya prosedur pelaksanaan eksekusi tidak dilaksanan sesuai ketentuan. Seperti misalnya eksekusi yang dilakukan dengan penjualan di bawah tangan hanya boleh dilakukan setelah lewat waktu 1 (satu) bulan sejak diberitahukan secara tertulis kepada pihak-pihak yang berkepentingan dan diumumkan minimal dalam 2 (dua) surat kabar yang beredar di daerah yang bersangkutan. Ini umumnya tidak dilakukan, dan biasanya Finance akan menggunakan jasa debt collector yang langsung mendatangi debitor dan mengambil kendaraan obyek jaminan dan kemudian oleh finance akan menjualnya kepada pedagang yang sudah menjadi relasinya. Hasil penjualan tidak diberitahukan kepada debitur apakah ada sisa atau masih ada kekurangan dibandingkan dengan hutang debitur. Sesungguhnya terhadap eksekusi yang bertentangan dengan ketentuan Pasal 29 Undang-Undang Nomor 42 Tahun 1999 berakibat eksekusi tidak sah sehingga pihak pemberifidusia (debitur) dapat menggugat untuk pembatalan.

\section{Pelanggaran oleh pihak debitur}

Selain dilakukan oleh pihak kreditur, pelanggaran hukum terhadap ketentuan dalam Undang-Undang Nomor 42 Tahun 1999 juga dapat dilakukan oleh pihak debitur. Pelanggaranpelanggaran yang sering dilakukan debitur adalah sebagai berikut:

a. Melakukan tindakan tanpa seijin penerima fidusia (kreditur).

Perbuatan atau tindakan tanpa seijin penerima fidusia oleh debitur umumnya adalah adalah pemberi fidusia (debitur) menggadaikan, mengalihkan atau menyewakan obyek jaminan fidusia tanpa seijin penerima fidusia (kreditur). Tindakan ini biasanya dilakukan oleh debitur yang telah mendapatkan pembiayaan dari perusahaan finance untuk pembelian kendaraan bermotor, di mana hutangnya belum lunas tapi kendaraannya telah digadaikan secara di bawah tangan kepada pihak ketiga. Terhadap perbuatan tersebut, Pasal 36 Undang-Undang Nomor 42 Tahun 1999 telah mengatur ancaman pidana bagi debitur yang mengadaikan atau mengalihakan obyek jaminan fidusia tanpa seijin kreditur yaitu diancam pidana penjara paling lama 2 (dua) tahun dan denda paling banyak Rp. 50.000.000,- (lima puluh juta rupiah).

\footnotetext{
Dalam Pasal 29 Undang-Undang Nomor 42 Tahun 1999 tentang Jaminan Fidusia diatur mengenai cara melakukan eksekusi yaitu: 1. Pelaksanaan title eksekutorial sebagaimana dimaksud dalam Pasal 15 ayat (2) Undang-Undang Nomor 42 Tahun 1999. Dalam sertifikat jaminan fidusia terdapat irah-irah "DEMI KEADILAN BERDASARKAN KETUHANAN YANG MAHA ESA" sehingga mempunyai kekuatan eksekutorial yang sama dengan putusan pengadilan yang telah memperoleh kekuatan hukum yang tetap. 2. Penjualan benda obyek jaminan fidusia atas kekuasaan penerima fidusia sendiri melalui pelelangan umum; 3.Penjualan di bawah tangan yang dilakukan berdasarkan kesepakatan antara pemberi dan penerima fidusia untuk memperoleh harga tertinggi yang menguntungkan kedua belah pihak.
} 


\section{R durnal}

Media Pembinaan Hukum Nasional

b. Menurunkan kualitas obyek jaminan fidusia.

Umumnya perbuatan ini dilakukan oleh debitur dengan mengubah dan atau mengganti isi dari benda yang menjadi obyek jaminan sehingga kualitasnya menjadi turun (jelek). Misalnya mengganti onderdil kendaraan bermotor dengan onderdil palsu atau onderdil bekas.

Perbuatan debitur tersebut tidak dapat dibenarkan karena pada saat ditandatanganinya perjanjian kredit dan perjanjian jaminan fidusia, hak kepemilikan atas obyek jaminan fidusia telah "beralih" dari pemberi fidusia (debitur) kepada penerima fidusia (kreditur), sehingga pemberi fidusia (debitur) hanya "dianggap sebagai penyewa" yang mempunyai kewajiban untuk menjaga, memelihara dan memakai obyek jaminan yang dikuasainya dengan baik.

c. Menjaminkan kembali obyek fidusia

Seringkali terjadi debitur menjaminkan kembali obyek jaminan fidusia kepada pihak lain. Sesungguhnya dalam prinsip jaminan fidusia terdapat larangan untuk melakukan fidusia ulang sebagaimana diatur dalam Pasal 17 Undang-Undang tentang Jaminan Fidusia. Hal ini ditujukan untuk melindungi kepentingan pihak kreditur yang telah memberikan pinjaman kepada debitur. Ketentuan tersebut sangat logis karena atas obyek jaminan fidusia dimaksud hak kepemilikannya telah "beralih" dari pemberi fidusia (debitur) kepada penerima fidusia (kreditur) sehingga tidak mungkin lagi dijaminkan kepada pihak lain. Apabila atas benda yang sama menjadi obyek jaminan fidusia lebih dari satu perjanjian jaminan fidusia maka hak yang didahulukan diberikan kepada pihak yang lebih dahulu mendaftarkannya di Kantor Pendaftaran Fidusia.

\section{E. PENUTUP}

\section{Kesimpulan}

Berdasarkan pembahasan di atas, pembiayaan konsumen merupakan salah satu alternatif pembiayaan yang dapat diberikan kepada konsumen atas suatu barang dengan pembayaran angsuran yang dilakukan secara berkala. Perjanjian pembiayaan umumnya disertai barang jaminan baik jaminan utama, jaminan pokok, dan jaminan tambahan untuk meng antisipasi terjadinya wanprestasi atau kemacetan dalam pengembalian kredit. Salah satu jaminan tambahan dalam dalam perjanjian pembiayaan konsumen adalah jaminan fidusia. Untuk memberikan legitimasi bagi para pihak maka perjanjian dibuat dengan akta okta otentik, dan didaftarkan pada kantor pendaftaran fidusia guna mendapatkan hak preference bagi kreditur. Berdasarkan praktek, perjanjian pembiayaan konsumen dengan jaminan fidusia belum sepenuhnya dipahami oleh debitur. $\mathrm{Hal}$ ini terungkap setelah terjadi persengketaan antara kreditur dan debitur dan terjadinya eksekusi terhadap jaminan fidusia.

Eksekusi atas obyek jaminan dalam dalam perjanjian pembiayaan konsumen masih banyak mengalami masalah. Permasalahan ini umumnya terjadi karena tidak dilaksanakannnya kewajiban-kewajiban yang harus ditunaikan oleh pihak kreditur, seperti tidak dilaksanaannya pendaftaran jaminan fidusia pada kantor pendaftaran fidusia sebagaimana diatur dalam undang-undang jaminan fidusia dan peraturan pelaksanaannya. Disamping itu informasi dan pemahaman yang kurang dari debitur atas jaminan fidusia juga mengakibatkan penyelesaian sengketa antara debitur dan kreditur tidak elegan. 


\section{R dunchal HTSVINDING}

\section{Saran}

Talangan pembiayaan oleh lembaga pembiayaan konsumen kepada debitur yang lebih banyak menimbulkan sifat-sifat komsumtif masyarakat karena mereka belum memahami jaminan fidusia atas perjanjian pembiayaan konsumen sehingga seringkali apabila terjadi wanprestasi mereka belum rela untuk dilakukan eksekusi atas obyek jaminan. Oleh karena itu perlu dilakukan sosialisasi terhadap masyarakat mengenai kerugian dan dampak negatif dari penerimaan talangan dari lembaga pembiayaan konsumen.

Penyelesaian sengketa perjanjian lembaga pembiayaan konsumen dengan jaminan fidusia tidak elegan bahkan cenderung menimbulkan sengketa yang kadang menjurus kearah kriminal. Oleh karena itu proses eksekusi atas obyek jaminan dari perjanjian pembiayaan konsumen harus dilaksanakan sesuai dengan prosedur yang telah ditentukan.

\section{DAFTAR PUSTAKA}

\section{Buku}

Fuady, Munir, Jaminan Fidusia, Cet. II, (Bandung: Citra Aditya Bakti, 2003).

Fuady, Munir, Jaminan Fidusia, (Bandung: PT. Citra Aditya, 2000).

Hamzah, A., dan Senjun Manullang, Lembaga Fidusia Dan Penerapannya Di Indonesia, (Jakarta: Indhill Co., 1987).

HS, H. Salim, Perkembangan Hukum Kontrak Diluar KUP Perdata, (Jakarta: PT. Raja Grafindo Persada, 2008).

Kamelo, Tan, Hukum Jaminan Fidusia Suatu Kebutuhan Yang Didambakan, Edisi Pertama, Cetakan Kedua, (Bandung: Alumni, 2006)

Satrio, J., Hukum Jaminan, Hak Jaminan Kebendaan Fidusia, (Bandung: Citra Aditya Bakti, 2002).

Soekanto, Soerjono dan Sri Mamudji, Penelitian Hukum Normati: Suatu Tinjauan Singkat, (Jakarta: CV. Rajawali, 1990)

Sunaryo, Hukum Lembaga Pembiayaan, (Jakarta: Sinar Grafika, 2008).

Supomo, R., Hukum Acara Perdata Pengadilan Negeri, (Jakarta: Pradnya Paramita, 1980)

Sutarno, Aspek-Aspek Hukum Perkreditan Pada Bank, (Bandung: Alfabeta, 2004)

Tiong, Oey Hoey, Fiducia Sebagai Jaminan UnsurUnsur Perikatan, Cet. II, (Jakarta: Ghalia Indonesia, 1985).

Widjaja, Gunawan \& Ahmad Yani, Jaminan Fidusia (Seri Hukum Bisnis), Cet. II, (Jakarta: Raja Grafindo Persada, 2001).

Widjaja, Gunawan, \& Ahmad Yani, Jaminan Fidusia, (Jakarta: PT. Raja Grafindo Persada, 2000). 